\title{
Comparison of hair and nail ethyl glucuronide concentrations
}

\section{Saç ve tırnakta etil glukuronid konsantrasyonlarının karşılaştırılması}

\author{
Ramazan Karanfil ${ }^{1}$, Alper Keten ${ }^{2}$, Cem Zeren $^{3}$, Emine Nur Rifaioğlu ${ }^{4}$, M. Tuğrul Göktaş ${ }^{5}$
}

\begin{abstract}
Objective: Alcohol abuse remains to be an important problem in the world. In forensic medicine practice, alcohol and its metabolites should be detected in the body in order to determine whether a person has taken alcohol or not. Therefore, detection of ethyl glucuronide in such keratinous tissues as nails and hair following alcohol intake is important. In the present study, we compared hair ethyl glucuronide concentrations with nail ethyl glucuronide (EtG) concentrations.
\end{abstract}

Methods: Hair and nail specimens were obtained from a total of 16 people taking alcohol. The specimens were analyzed with LC/MS/MS technique. Ethyl glucuronide concentrations of hair specimens were compared with those of nail specimens.

Results: Ethyl glucuronide concentrations were 1.3365.67 (+/- SD16.57) ppb in hair specimens and 4.27225.03 (+/- SD 59.77) ppb in nail specimens. Hair ethyl glucuronide concentrations were correlated with nail ethyl glucuronide concentrations $(r=0,808, p<0.001)$.

Conclusion: This study showed that ethyl glucuronide concentrations in hair and nails could be determined. This suggests that detection of nail ethyl glucuronide concentrations can be useful in people without hair. In addition, there was a significant relationship between hair and nail ethyl glucuronide concentrations.

Key words: Alcohol, EtG, hair, nail

\section{ÖZET}

Amaç: Alkol kullanımı Dünyada önemli bir sorun olarak devam etmektedir. Adli tıp pratiğinde, kişinin alkol alıp almadığını ortaya koyabilmek için vücutta alkol ve metabolitlerinin tespiti gerekmektedir. Bu amaçla, alkol alımından sonra tırnak ve saç gibi keratinöz dokularda ethyl glucuronide (EtG) tespiti önem taşımaktadır. Bu çalışmada tırnak ve saç dokusunda tespit edilen EtG miktarlarının korelasyonunu araştırdık.

Yöntemler: Kronik alkol kullanan toplam 16 olgunun saç ve tırnak dokuları alındı. Alınan saç ve tırnak örnekleri LC/ MS/MS yöntemi ile analiz edildi. Saç ve tırnak dokusundan elde edilen sonuçlar karşılaştırıldı.

Bulgular: Analizlerde saç örneklerinde EtG 1.33-65.67 (+/- SD16.57) ppb arasında bulundu. Tırnak dokusunda EtG 4.27-225.03 (+/- SD 59.77) ppb aralığında analiz edildi. Saç dokusu ile tırnak dokusu EtG değerleri arasında anlamlı $(r=0,808, p<0.001)$ bir ilişkinin varlığı gösterildi.

Sonuç: EtG'nin saç ve tırnak dokusunda gösterilebileceği ortaya kondu. Özellikle saçı olmayan kişilerde alkol metabolitinin tespiti için tırnak dokusunun kullanılabileceğini düşünüyoruz. Ayrıca saç ve tırnak dokusundaki EtG oranları arasında anlamlı bir ilişki vardır.

Anahtar kelimeler: Alkol, EtG, saç, tırnak

\footnotetext{
${ }^{I}$ Sütcü Imam University, Medical Faculty, Department of Forensic Medicine, Kahramanmaraş, Turkey

${ }^{2}$ Council of Forensic Medicine, Kahramanmaraş Branch, Kahramanmaraş, Turkey

${ }^{3}$ Mustafa Kemal University, Medical Faculty, Department of Forensic Medicine, Hatay, Turkey

${ }^{4}$ Mustafa Kemal University, Medical Faculty, Department of Dermatology, Hatay, Turkey

${ }^{5}$ Atatürk Education and Research Hospital, Department of Pharmacology, Ankara, Turkey
}

Yazışma Adresi /Correspondence: Ramazan Karanfil, 


\section{INTRODUCTION}

Alcohol consumption has increased in the world throughout the years [1]. Therefore, measurement of alcohol concentrations in the body following alcohol intake remains to be an important issue in forensic medicine practice. Minor metabolites of ethyl alcohol including ethyl glucuronide (EtG), fatty acid ethyl esters (FAEEs), ethyl sulphate (EtS) and phosphatidylethanol (PEth) can be used to determine alcohol concentrations in the body [2-6].

EtG, a minor non-oxidative metabolite of ethanol, is formed by net addition of glucuronic acid to ethanol. The UDP-glucuronosyltransferase (UGT) superfamily of enzymes, using UDP-glucuronic acid as a cofactor, catalyzes this clearance pathway. Serum and/or urine ethanol levels can normally be measured only for a few hours after alcohol intake; however, urinary EtG levels have been measured for 3-5 days after alcohol consumption [7,8]. Hair and nail EtG concentrations can be detected even months after alcohol intake. The metabolite EtG has been used to detect alcohol in biological fluids such as blood, urine, sweat and intraocular fluid (humor) and in tissues such as bone, hair, muscle, bone marrow and fat to determine alcohol intake [9-13].

In recent times, there have been studies on detection of EtG concentrations in nail tissues $[14,15]$. Nail and hair are keratinous tissues capable of storing substances and their metabolites. Therefore, these tissues are utilized in forensic medicine analyses in cases of toxicities [16-18].

In the present study, we aimed to detect EtG in hair and nail tissues, commonly used in toxicological analyses, with LC/MS/MS and to investigate whether hair EtG concentrations were correlated with nail EtG concentrations. This is the first study to compare hair EtG concentrations with nail EtG concentrations.

\section{METHODS}

\section{Ethics statement and subjects}

This study included 16 alcohol users. Ethical approval was obtained from the ethical committee of Mustafa Kemal University. Hair and nail specimens were collected from people presenting to the outpatient clinic of Forensic Medicine at Mustafa Kemal
University for examination. The only inclusion criterion was chronic alcohol intake. All participants gave informed consent. Nails of the hands were obtained with a pair of clean nail scissors without damaging the hyponychium (the quick). They were kept in eppendorf tubes. To collect hair specimens, a strand of hair was fixed in the vertex posterior region and cut as close to the skin as possible. The specimens were analyzed with LC/MS/MS.

\section{Chemicals, reagents and materials}

We acquired EtG and deuterium-labeled EtG-d5 standards (internal standard) from Medichem (Stuttgart, Germany), hypergraded solvents for LC-MS LiChrosolv from Merck KGaA (Darmstadt, Germany) and deionized water from the Mili-Q (Millipore, Bedford, USA) water purification system.

\section{Calibrator, control and internal standard spiking solutions}

10 ppm of EtG Standard was prepared as in the following: first, $1 \mathrm{mg}$ of EtG was mixed with $1 \mathrm{mg}$ methanol and $250 \mu \mathrm{l}$ of the resultant solution was added methanol until a volume of $25 \mathrm{~mL}$ was obtained using a $25-\mathrm{mL}$ volumetric flask. Preparation of $2500 \mathrm{ppb}$ of EtG-d5 Standard was as follows: $0.25 \mathrm{mg}$ of EtG-d5 was mixed with $1 \mathrm{ml}$ methanol and methanol was added to $250 \mu \mathrm{l}$ of the resultant solution until a volume of $25 \mathrm{~mL}$ was obtained using a $25-\mathrm{mL}$ volumetric flask. The above-mentioned standards were utilized to prepare standard solutions of 2, 5, 10, 20, 50, 100, 200, 1000 and 2000.

\section{Specimen preparation}

Fingernail specimens were powderized and weighed with a sensitive scale and 50mg specimen was put in a tube. Each specimen was added a mixture of $50 \%$ acetonitrile and $50 \%$ water and kept in an ultrasonic bath at $25^{\circ} \mathrm{C}$ for 2 hours. Then, the specimen was added internal standard of $50 \mu 1$ and mixed with vortex. It was subjected to centrifuge at 4000 rpm for 10 minutes. Following centrifuge, two $\mathrm{ml}$ extract was obtained from the upper part and put in the autosampler vials. Mixtures of water/acetonitrile/methanol, acetonitrile/water of $80 \%$ and acetonitrile/water of $50 \%$ were used for extraction of each specimen and the mixture of $50 \%$ acetonitrile $/ 50 \%$ water yielded the best result. 


\section{LC-MS/MS conditions}

An Agilent Technologies 1200 system consisting of a G1367C autosampler, a G1379B degasser, G1312B binary pump was utilized to analyze the specimens. Two Zorbax Hilic Plus $(4.6 \times 100 \mathrm{~mm}$, 3.5 micron particle size) serial connected columns were employed to achieve separation. Reversereverse chromatographic technique was preferred. The column was kept at $25^{\circ} \mathrm{C}$ in a G1316B Thermostatted Column Compartment (Wilmington, DE, USA). The solvent system which we used was a gradient involving A (1mM NH4Ac) and B (acetonitrile) at a flow rate of $0.8 \mathrm{~mL} / \mathrm{min}$. The solvent program was held at B at $65 \%$ from 0.0 min to 2.2 min. Solvent B was reduced to $20 \%$ between 2.3 min and $9.5 \mathrm{~min}$ and increased to $20 \%$ at $5.1 \mathrm{~min}$ and held at $65 \%$ until $10.0 \mathrm{~min}$. The detector Agilent Technologies 6460 Triple Quad LC/MS System with electro-spray ionization (ESI) in the negative mode (Wilmington, DE, USA) was used. The capillary voltage was $4000 \mathrm{~V}$, the nozzle voltage was $0 \mathrm{~V}$ and the desolvation gas (nitrogen) was heated until it was $350{ }^{\circ} \mathrm{C}$ with a flow of $11 \mathrm{l} / \mathrm{min}$. Nebulazator pressure was 50 psi. The sheath gas (nitrogen) was heated till it was $350{ }^{\circ} \mathrm{C}$ and released at $11 \mathrm{l} / \mathrm{min}$.

The $\mathrm{m} / \mathrm{z} 226.0>75.0$ (quantification ion) transition and the $\mathrm{m} / \mathrm{z} 226.0>85.0$ (qualifying ion) transition were utilized to monitor the internal standard (ETG-d5). The $\mathrm{m} / \mathrm{z} 221.0>75.0$ (quantification ion) and $\mathrm{m} / \mathrm{z} 221.0>85.0$ (qualifying ion) transitions were employed for monitoring EtG. A fragmentor voltage of $100 \mathrm{~V}$ and collision energy of $12 \mathrm{~V}$ was used in all three transitions. MassHunter

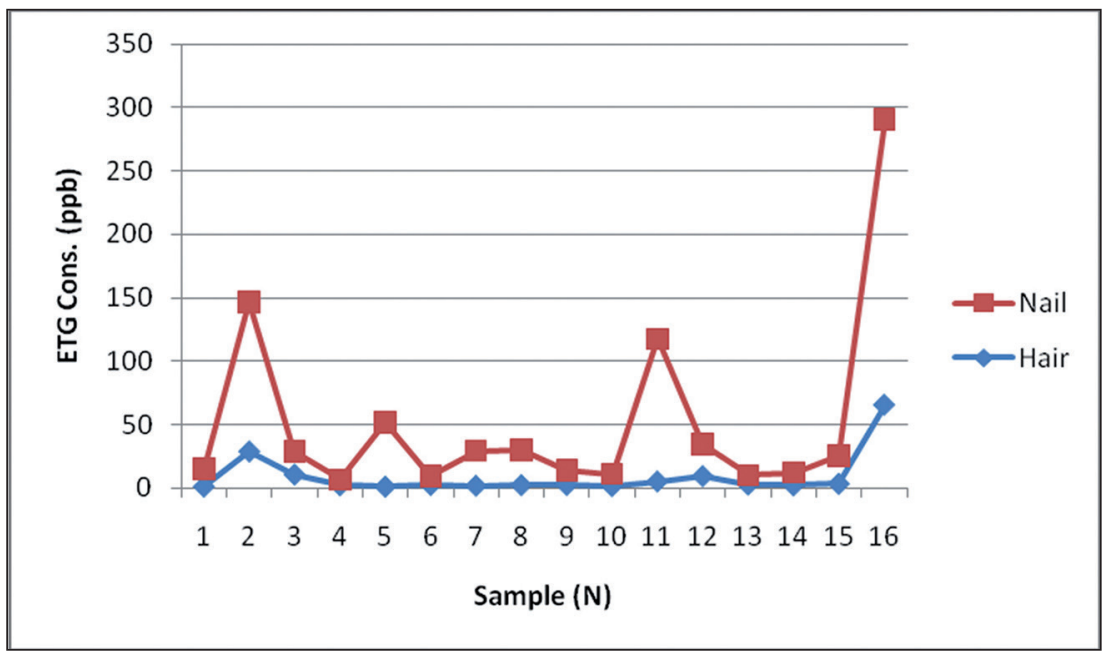

B.04.01 (Wilmington, DE, USA) was utilized to process obtained data.

\section{Identification criteria and validation}

Identification criteria were the ones used in the original study, the results of which we attempted to replicate in the present study, and validation was also performed as in the original study [19].

\section{Statistical analysis}

Statistical analyses were made with SPSS Statistics version 15.0. Evaluation of the associations of mast point and nail EtG concentrations were performed using Pearson's correlations. Comparisons of the means of EtG concentrations in mast point and fingernails were made using independent student $t$-test (t). $p<0.001$ was accepted as significant.

\section{RESULTS}

The mean age of the participants was $28.3 \pm 4.75$ years. All 16 participants included in the study were male. EtG concentrations were 1.33-65.67 ppb in hair specimens and 4.27-225.03 ppb in nail specimens (Figure 1).

The calibration curve for standard solutions is shown in Figure 2.

There was a significant relation between hair EtG concentrations and nail EtG concentrations $(r=0,808, p<0.001)$ (Figure 3). Pearson correlations revealed similar EtG concentrations in hair and nail specimens $(r=0.899, \mathrm{p}<0.001)$.
Figure 1. EtG concentrations in hair and nail specimens 


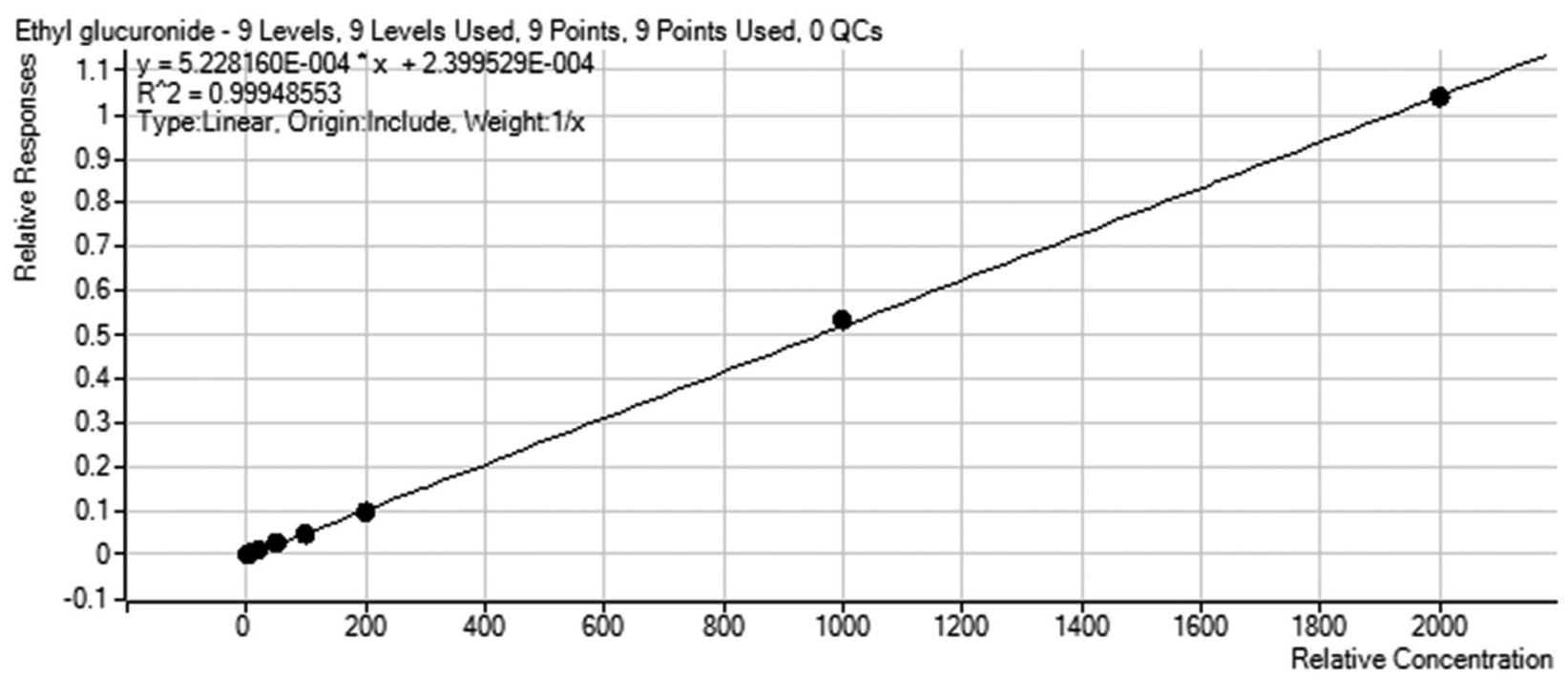

Figure 2. Calibration Curve for Standard Solutions

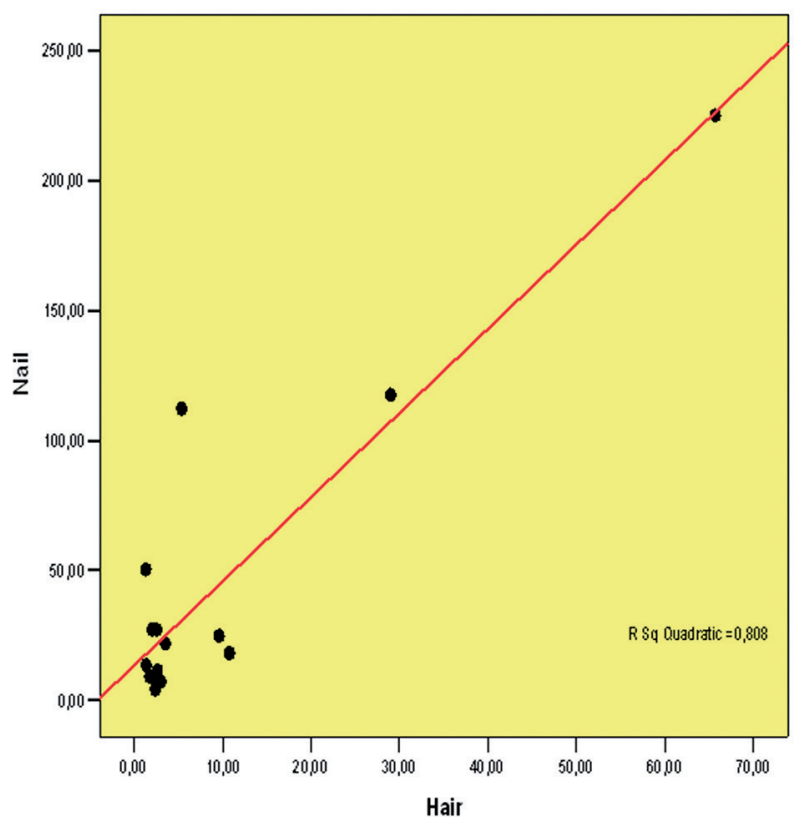

Figure 3. Relation between hair EtG concentrations and nail EtG concentrations

\section{DISCUSSION}

In the present study, we found similar EtG concentrations in hair and nail specimens after alcohol intake. In fact, there was a significant correlation between hair and nail EtG concentrations. Biological fluids may not be used in postmortem forensic toxicological examinations especially when putrefaction and mummification occur and when the in- tegrity of the body is distorted in plane crashes and severe burns [20]. In such cases, stable tissues are required for analyses [21,22].

In vivo studies have shown that time to determine EtG varies with biological fluids [12]. In a study using postmortem biological fluids, EtG was found to remain the longest in intraocular fluid, followed by urine and blood [13].

It has been reported in the literature that it is not possible to reveal EtG in blood and urine a period of time after alcohol intake. Although detection of EtG is more advantageous than that of ethanol, it can only be possible to show EtG in biological fluids such as blood and urine for a certain period of time [12]. Therefore, it is recommended that such compact tissues as hair and nail should be used since they allow detection of EtG for longer periods of time [23-25]. Jones et al. in their study on EtG analyses in hair and nail specimens emphasized that nail specimens could be used to reveal the behavior of alcohol intake [15]. Similarly, Morini et al. in a series of 15 cases showed EtG in nail specimens after alcohol intake [14]. In addition, several studies on EtG have revealed that hair and nail EtG concentrations are correlated with blood EtG concentrations $[14,23,24,26]$.

One study also reported that EtG analyses in specimens of hair, a keratinous tissue, had a high sensitivity and specifity (26). Indeed, it has been emphasized in several studies that EtG analyses in 
hair have a higher sensitivity and specifity than conventional indicators of EtG such as CDT and GGT [15,22-24,27].

In conclusion, hair and nail are keratinous tissues which are more stable and easier to obtain than biological fluids in detection of alcohol intake. This study revealed a correlation between hair and nail EtG concentrations. Therefore, both tissues can be useful in determination of alcohol intake. However, nail tissues can be preferable in cases of alopecia and in cases of short or no hair for various reasons.

\section{REFERENCES}

1. World Health Organization, Global status report on alcohol and health. Geneva 2011:9-12.

2. Bogdan C, Lech C, Maciej S. Nonoxidative metabolites of ethanol as a markers of recent alcohol drinking 2007;23:235-238.

3. Varga A, Alling C. Formation of phosphatidylethanol in vitro in red blood cells from healthy volunteers and chronic alcoholics. J Lab Clin Med 2002;140:79-83.

4. Aradottir S, Seidl S, Wurst FM, et al. Phosphatidylethanol in human organs and blood: a study on autopsy material and influences by storage conditions. Alcohol Clin Exp Res 2004;28:1718-1723.

5. Refaai MA, Nguyen PN, Steffensen TS, et al. Liver and adipose tissue fatty acid ethyl esters obtained at autopsy are postmortem markers for premortem ethanol intake. Clin Chem 2002;48:77-83.

6. Soderberg BL, Salem RO, Best CA, et al. Fatty acid esters, ethanol metabolites that reflect ethanol intake. Am J Clin Pathol 2003;119:94-99.

7. Foti RS, Fisher MB. Assessment of UDP-glucuronosyltransferase catalyzed formation of ethyl glucuronide in human liver microsomes and recombinant UGTs. Forensic Sci Int 2005; 153:109-116.

8. Schmitt G, Aderjan R, Keller T, Wu M. Ethyl glucuronide: an unusual ethanol metabolite in humans. Synthesis, analytical data, and determination in serum and urine. J Anal Toxicol 1995;19:91-94

9. Schloegl H, Rost T, Schmidt W, et al. Distribution of ethyl glucuronide in rib bone marrow, other tissues and body liquids as proof of alcohol consumption before death. Forensic Sci Int 2006;156:213-218.

10. Kerekes I, Yegles M, Grimm U, Wennig R. Ethyl glucuronide determination: Head hair versus non-head hair. Alcohol \& Alcoholism 2009;44:62-66.

11. Kintz P, Villain M, Vallet E, et al. Ethyl glucuronide: Unusual distribution between head hair and pubic hair. Forensic Sci Int 2008;176: 87-90.
12. Høiseth G, Bernard JP, Karinen R, et al. A pharmacokinetic study of ethyl glucuronide in blood and urine: Applications to forensic toxicology. Forensic Sci Int 2007;172:119-124.

13. Keten A, Tümer AR, Odabasi AB. Measurement of ethyl glucuronide in vitreous humor with liquid chromatographymass spectrometry. Forensic Sci Int 2009;193:101-105.

14. Morini L, Colucci M, Ruberto MG, Groppi A. Determination of ethyl glucuronide in nails by liquid chromatography tandem mass spectrometry as a potential new biomarker for chronic alcohol abuse and binge drinking behavior. Anal Bioanal Chem 2012;402:1865-1870.

15. Jones J, Jones M, Plate C, et al. Chromatography-Tandem Mass Spectrometry assay to detect ethyl glucuronide in human fingernail: comparison to hair and gender differences. Am J Analytic Chem 2012;3:83-91.

16. Pounds A, Pearson EF, Turner TD. Arsenic in finger-nails. Forensic Sci Soc 1979;19:165-173.

17. Wihelm M, Hafner D, Lombeck I, Ohnesorge FK. Monitoring of cadmium, copper, lead and zinc status in young children using toenails: comparison with scalp hair. Sci Total Environ 1991;103:199-207.

18. Lemos NP, Anderson RA, Robertson JR. Nail analysis for drugs of abuse: extraction and determination of Cannabis in fingernails by RIA and GC-MS. J Anal Toxicol 1999;23:147-152.

19. Keten A, Zeren C, Arslan MM, et al. Determination of ethyl glucuronide in fingernails by LC/MS-MS. Rom J Leg Med 2013;21:67-72.

20. Brinkmann B, Madea B. Handbuch gerichtliche Medizin. Medizinrecht 2004;22:150-165.

21. Skopp G. Preanalytic aspects in postmortem toxicology. Forensic Sci Int 2004;142:75-100

22. Levisky JA, Bowerman DL, Jenkins WW, et al. Drugs in postmortem adipose tissues: evidence of antemortem deposition. Forensic Sci Int 2001;121:157-160.

23. Wurst MF, Skipper GE, Weinmann W. Ethyl glucuronidethe direct ethanol metabolite on the threshold from science to routine use. Addiction 2003;98:51-56.

24. Politi L, Zucchella A, Morini L, et al. Markers of chronic alcohol use in hair: comparison of ethyl glucuronide and cocaethylene in cocaine users. Forensic Sci Int 2007;172: 23-27.

25. Morini L, Politi L, Polettini A. Ethyl glucuronide in hair A sensitive and specific marker of chronic heavy drinking. Addiction 2009;104:915-920.

26. Neumann T, Helander A, Dahl H, et al. Value of ethyl glucuronide in plasma as a biomarker for recent alcohol consumption in the emergency room, Alcohol \& Alcoholism 2008;43: 431-435.

27. Agius R, Nadulski T, Kahl HG, et al. Validation of a headspace solid-phase microextraction-GC-MS/MS for the determination of ethyl glucuronide in hair according to forensic guidelines. Forensic Sci Int 2010;196:3-9. 